\title{
Status antioksidan dan oksidatif laki-laki yang mengalami kegemukan dengan pemberian minuman rosela ungu
}

\author{
Sriyanti*, Evy Damayanthi, Faisal Anwar
}

\begin{abstract}
Background : Rosela (Hibiscus sabdariffa L.) is an anthocyanin-rich plant that has good antioxidant capacity. However, the utilization was limited to red roselle, while previous studies showed that anthocyanin content was found to be higher in the thick roselle.therefore, this is an opportunity to develop purple roselle products as a preventive effort for degenerative diseases in men with fatness. Subjects in this study were male by considering the effect of estrogen on women which could play a role in suppressing oxidative stress.

Objectives: This study aimed to analyze antioxidant (SOD/Superoxide dismutase) and oxidative status

(MDA/malondialdehyde) level in obese adult men after administration of purple rosela drinks.

Methods : This study was quasi-experimental with pre-post test. Eighteen obese subjects in the security unit were divided into two groups, namely the intervention group and control group. Intervention group $(n=9)$ was given purple rosela drinkin the amount of $480 \mathrm{~mL} /$ day, while the control group $(n=9)$ was given an equivalent amount of purple rosela drink without rosela. The subjects were daily administered for 6 weeks. Characteristic, anthropometric, food consumption and blood sample data were collected at the beginning and end of the intervention. Data analysis was performed by descriptively, paired t-test, independent t-test, ANCOVA.

Results : The analysis showed that purple rosela drink tend to increase SOD levels $(0.45 \pm 0.14 ; 1.35 \pm 0.71 ; p$-value = 0.008$)$ but this value was not significantly different from the control group ( $p$-value $=0.128)$. MDA levels did not significantly different between the intervention and control groups $(0.025 \pm 0.083 ;-0.125 \pm 0.60 ; p$-value $=0.473)$.

Conclusion : These results showed that administering $480 \mathrm{ml}$ of purple rosela drink did not improve antioxidant and oxidative status in obese adult men.
\end{abstract}

Keywords : anthocyanin; antioxidant; obesity; purple roselle; stres oksidatif

\begin{abstract}
ABSTRAK
Latar Belakang : Rosela (Hibiscus sabdariffa L.) merupakan tanaman kaya antosianin yang memiliki kapasitas antioksidan baik. Namun, pemanfaatan masih terbatas pada rosela merah, sementara penelitian sebelumnya menunjukkan bahwa kandungan antosianin ditemukan lebih tinggi pada kelopak rosela yang berwarna pekat. Hal tersebut menjadi peluang pemanfaatan dan pengembangan produk berbahan dasar rosela ungu sebagai salah satu upaya preventif penyakit degeneratif pada laki-laki dengan kegemukan. Subjek dalam penelitian berjenis kelamin laki-laki dengan pertimbangan efek hormon estrogen pada perempuan yang dapat berperan menekan stres oksidatif.

Tujuan : Penelitian ini bertujuan untuk menganalisis status kadar SOD (superoksida dismutase) dan oksidatif (MDA/malondialdehid) pada laki-laki dewasa gemuk setelah pemberian minuman rosela ungu.

Metode : Penelitian ini merupakan kuasi eksperimental dengan pre-post test. Delapan belas subjek laki-laki gemuk satuan pengaman dibagi dua kelompok yaitu kelompok intervensi $(n=9)$ mendapatkan minuman ekstrak rosela ungu dan kontrol $(n=$ 9) mendapatkan minuman tanpa rosela masing-masing dengan volume $480 \mathrm{~mL} / \mathrm{hari}$ selama $6 \mathrm{minggu}$. Data karakteristik, antropometri, konsumsi makanan dan sampel darah dikumpulkan di awal dan akhir intervensi. Analisis data dilakukan secara deskriptif, paired t-test, independent t-test, ANCOVA.

Hasil : Hasil analisis menunjukkan pemberian minuman ekstrak rosela ungu cenderung meningkatkan kadar SOD (0.45 \pm 0.14 ; $1.35 \pm 0.71 ; p$-value $=0.008)$ namun tidak berbeda signifikan dengan kelompok kontrol $(p$-value $=0.128)$. Kadar MDA tidak berbeda signifikan antara kelompok intervensi dan kontrol $(0.025 \pm 0.083 ;-0.125 \pm 0.60 ; p$-value $=0.473)$.

Simpulan : Hasil ini memperlihatkan bahwa pemberian $480 \mathrm{ml}$ minuman ektrak rosela ungu tidak memperbaiki status antioksidan dan oksidatif pada laki-laki dewasa gemuk.
\end{abstract}

Kata Kunci : antosianin; antioksidan; obesitas; rosella ungu; stres oksidatif

\section{PENDAHULUAN}

Kegemukan ditandai dengan peningkatan berat badan yang menyebabkan akumulasi lemak tubuh berlebihan dengan kategori indeks massa tubuh (IMT) $\geq 23,0 \mathrm{~kg} / \mathrm{m}^{2}{ }^{1}{ }^{1}$ Riskesdas (2018) menunjukkan bahwa prevalensi kegemukan yang meliputi kelebihan berat badan dan obesitas mengalami peningkatan dari tahun ke tahun. Penyebab kegemukan berkembang dari faktor gaya hidup seperti konsumsi alkohol ${ }^{2,3}$, merokok ${ }^{4}$,

Departemen Gizi Masyarakat, Fakultas Ekologi Manusia, Institut Pertanian Bogor. Jl. Lingkar Kampus, Babakan, Dramaga, Bogor, Jawa Barat 16680, Indonesia *Korespondensi : E-mail: dya_tillah@yahoo.com, Telp/HP. 085255505294 
konsumsi makanan tinggi lemak dan konsumsi buah sayur rendah ${ }^{5}$, serta aktivitas fisik yang rendah ${ }^{6}$. Studi menunjukkan bahwa orang gemuk akan mengalami stres oksidatif dan peradangan kronis yang dapat berkembang menjadi penyakit degeneratif seperti penyakit kardiovaskuler, diabetes mellitus, dan kanker. Sementara itu, penyakit degeneratif menjadi penyebab kematian terbesar di dunia saat ini. Satuan pengaman (satpam) merupakan salah satu profesi dengan pola aktivitas yang berisiko mengalami kegemukan. Hal ini disebabkan karena dalam pelaksanaan tugasnya lebih banyak melakukan aktivitas dengan intensitas ringan. Apriawan (2013) juga menemukan bahwa $43,06 \%$ satpam mengalami kegemukan.

Peningkatan stres oksidatif pada kegemukan disebabkan oleh sintesis sitokin pro-inflamasi pada jaringan adiposa yang memengaruhi respon inflamasi dengan memproduksi spesies oksigen reaktif (ROS). ROS dalam jumlah berlebih akan mengoksidasi komponen lipid membran sel sehingga terjadi peroksida lipid. Penelitian sebelumnya menunjukkan bahwa terjadi peningkatan stres oksidatif pada individu dengan kegemukan dibandingkan individu dengan berat badan normal yang ditandai dengan peningkatan peroksida lipid, seperti produk MDA (malondialdehid). Superoksida dismutase (SOD) merupakan antioksidan enzim yang berperan sebagai sistem pertahanan pertama terhadap senyawa radikal bebas. Namun beberapa penelitian menunjukkan aktivitas antioksidan seperti SOD pada kegemukan lebih rendah dibandingkan pada berat badan normal. ${ }^{7,8}$ Hal ini memperlihatkan terjadi ketidakseimbangan antara aktivitas antioksidan dengan produksi radikal bebas dalam tubuh. Pemberian makanan/minuman kaya antioksidan diharapkan dapat meningkatkan pertahanan antioksidan tubuh yang selanjutnya dapat mengurangi stres oksidatif.

Antosianin merupakan kelompok flavonoid yang telah terbukti memiliki efek menguntungkan dalam bidang kesehatan, diantaranya meningkatkan antioksidan tubuh ${ }^{9,10}$ memperbaiki profil lipid ${ }^{11}$, memperbaiki status oksidatif ${ }^{12,13}$, efek anti inflamasi ${ }^{14,15}$, serta menurunkan berat badan ${ }^{16,17}$. Rosela merupakan salah satu tanaman kaya antosianin ${ }^{18}$ dengan antioksidan kuat $^{19}$ dan memiliki efek positif terhadap aktivitas antioksidan dan penurnan peroksida lipid pada tikus ${ }^{20,21}$. Penelitian dengan subjek manusia memberikan kapsul rosela (@kapsul 450 mg ekstrak rosela) dengan kandungan antosianin 25,463 mg selama 6 minggu menunjukkan penurunan yang signifikan pada kadar MDA dan peningkatan kapasistas antioksdan total $(\text { TAC })^{22}$. Namun, sejauh ini pemanfaatan masih terbatas pada rosela merah., khususnya dalam bidang kesehatan.

Suatu penelitian menunjukkan bahwa kandungan antosianin rosela segar ungu lebih tinggi $(487,18 \mathrm{ppm})$ dibandingkan dengan rosela merah $(255,83 \mathrm{ppm})$ dengan pigmen sari rosela yang jauh lebih pekat pada rosela ungu. Penelitian lain menyatakan bahwa semakin pekat warna merah pada rosela menunjukkan kandungan antosianin yang semakin tinggi. Hasil yang serupa ditemukan oleh Tahir tahun 2017 yang membandingkan tiga jenis varietas rosela menunjukkan rosela dengan warna kelopak merah pekat memiliki kandungan antosianin paling tinggi dibanding dua varietas lainnya (rosela merah dan putih) ${ }^{23}$. Sementara itu, pemanfaatan rosela dalam bentuk crude (bubuk) tidak memberikan efek perbaikan pada biomarker stress oksidatif disebabkan karena konsentrasi polifenol yang rendah dibandingkan dalam bentuk ekstrak bubuk ${ }^{24}$. Oleh karena itu, penelitian ini bertujuan untuk menganalisis pengaruh intervensi minuman ekstrak kelopak rosela ungu terhadap SOD dan MDA laki-laki dewasa gemuk. Pemilihan subjek penelitian pada jenis kelamin laki-laki dengan pertimbangan bahwa adanya efek hormon estrogen pada perempuan yang dapat berperan dalam menekan stres oksidatif.

\section{BAHAN DAN METODE}

Desain penelitian adalah quacy experimental dengan pendekatan pre-post test. Subjek dipilih secara purposive sampling berdasarkan kriteria inklusi dan eksklusi. Penelitian dilakukan pada Januari sampai Mei 2018 di Kampus Institut Pertanian Bogor Dramaga, Kabupaten Bogor. Analisis kadar SOD dan MDA dilakukan di Laboratorium Departemen Biokimia dan Biologi Molekuler Fakultas Kedokteran Universitas Indonesia. Penelitian ini telah mendapatkan persetujuan etik dari Komite Etik Manusia Institut Pertanian Bogor dengan Nomor: 039/IT3.KEPMSM-IPB/SK/2018 serta informed consent dari semua subjek.

Subjek penelitian adalah satpam IPB dengan kriteria inklusi meliputi laki-laki gemuk berusia $30-55$ tahun dengan nilai IMT $\geq 23,0 \mathrm{~kg} / \mathrm{m}^{2}$ dan/atau lingkar pinggang $>90 \mathrm{~cm}$, tidak sedang menjalani pengobatan dari dokter, tidak sedang mendapatkan intervensi (minuman antioksidan) serupa, bersedia berpartisipasi dan menandatangani informed consent. Kriteria eksklusi pada penelitian ini adalah memiliki penyakit kronis atau penyakit kardiovaskular, memiliki penyakit atau riwayat penyakit lambung, rutin mengonsumsi suplemen antioksidan dan/atau fitofarmaka. Skrining dilakukan terlebih dahulu berdasarkan pengukuran IMT. Sebanyak 82 satpam gemuk yang ditemukan dari hasil skrining dan diwawancara untuk mendapatkan data karateristik sosial ekonomi, tingkat pengetahuan gizi, gaya hidup, serta konsumsi pangan dan ditampilkan secara deskriptif untuk mengetahui sebaran satpam gemuk. Namun 1 orang tidak mengisi kuesioner dengan lengkap sehingga dikeluarkan dari analisis data. Skrining kedua selanjutnya adalah berdasarkan kriteria inklusi dan ekslusi yang telah ditetapkan. Sebanyak 30 subjek memenuhi kriteria inklusi dan eksklusi yang selanjutnya 
dikelompokkan menjadi dua kelompok perlakuan. Total subjek hingga di akhir intervensi sebanyak 18 orang.

Bahan yang digunakan yaitu kelopak rosela kering yang didapatkan dari Blitar (Jawa Timur), garam, sukralosa, air, dan bahan-bahan kimia. Pembuatan minuman diawali dengan ekstraksi rosela ungu kering secara infusa dalam 1 liter air dengan suhu 70 sampai $80^{\circ} \mathrm{C}$. Campuran diaduk selama 15 menit dan kemudian disaring. Hasil filtrasi dipekatkan hingga 20 kali menggunakan evaporator untuk menghasilkan ekstrak rosela ungu. Minuman intervensi dibuat dari $10 \mathrm{~g}$ ekstrak rosela ungu (antosianin 40,58 $\mathrm{mg}$ ) dan dicampurkan dengan sukralosa $(0,05 \mathrm{~g})$, garam $(0,2 \mathrm{~g})$ dan air $(229,75$ $\mathrm{mL}$ ). Minuman dikemas dalam botol dengan volume 480 $\mathrm{mL}$ (81,16 mg antosianin). Sementara itu, kelompok kontrol diberikan minuman plasebo yang memiliki warna serupa dengan minuman intervensi berupa minuman sirup namun tidak mengandung antosianin dengan volume yang sama. Minuman intervensi/plasebo diberikan pada pagi hari untuk konsumsi dua kali sehari.

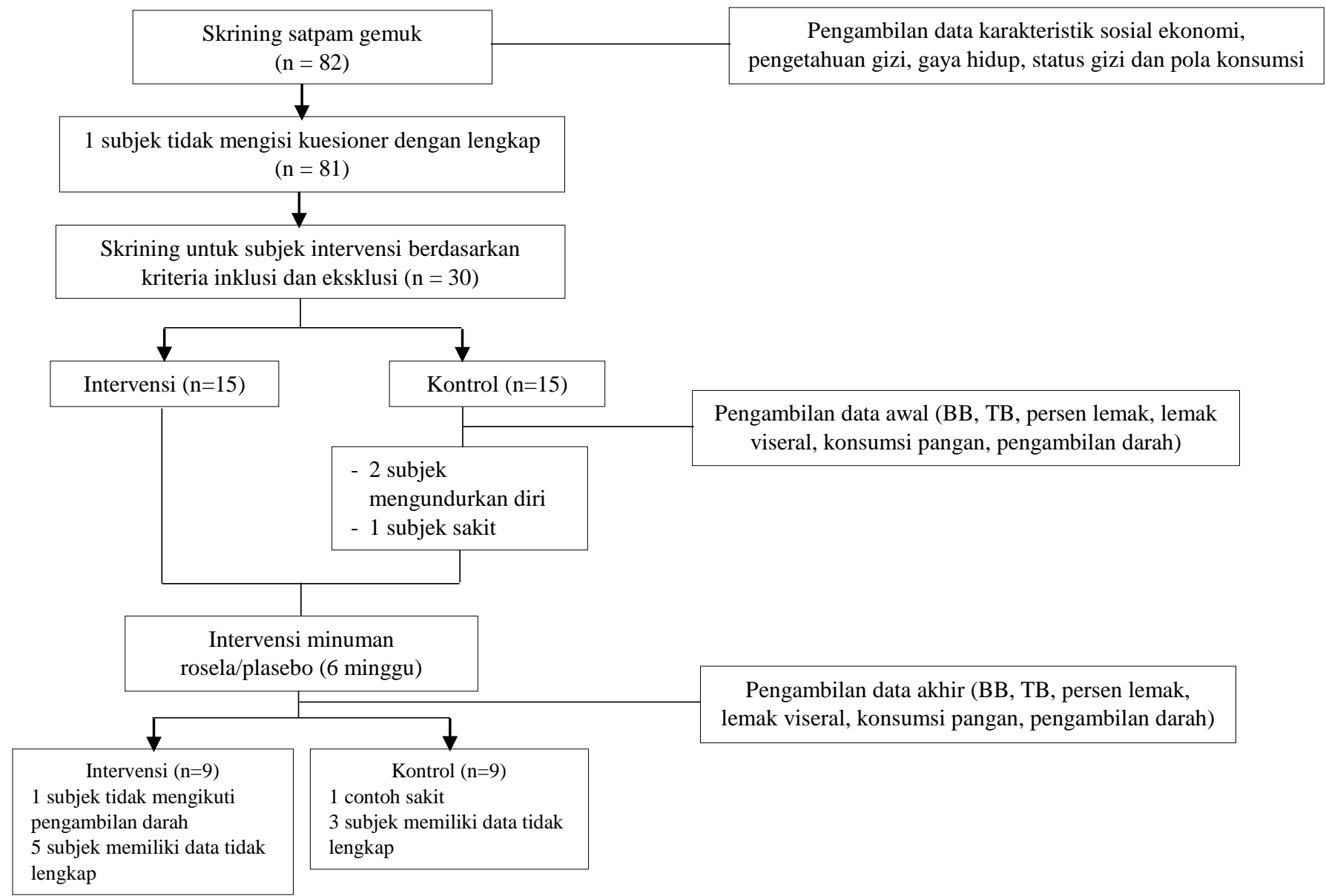

Gambar 1. Alur penelitian

Data yang dikumpulkan, diantaranya karakteristik sosial ekonomi dan pengetahuan gizi yang didapatkan melalui wawancara menggunakan kuesioner. Tingkat pengetahuan dikategorikan menjadi 3 kategori yaitu baik $(>80 \%-100 \%)$, sedang $(60 \%-80 \%)$, kurang $(<60 \%)$. Data gaya hidup, meliputi kebiasaan merokok dan tingkat aktivitas fisik. Data kebiasaan merokok dikumpulkan dengan menggunakan kuesiner, sementara data aktivitas fisik diperoleh dari formulir recall $2 \times 24 h$, diisi berupa jenis kegiatan yang dilakukan subjek dan lama waktu yang digunakan pada setiap aktivitas dalam 24 jam yang lalu untuk mendapatkan nilai physical activity level (PAL) berdasarkan FAO/WHO/UNU Expert Consultation 2001. PAL didapatkan dengan mengalikan jumlah energi yang dikeluarkan untuk setiap jenis kegiatan yang dilakukan dibagi 24 jam. Data antropometri, konsumsi pangan serta sampel darah dikumpulkan sebelum dan setelah intervensi. Data antropometri meliputi tinggi badan menggunakan mikrotois dengan ketelitian $0,1 \mathrm{~cm}$, lingkar pinggang menggunakan pita ukur dengan ketelitian $0,1 \mathrm{~cm}$, berat badan, persen lemak tubuh dan lemak viseral diukur menggunakan Bioelectrical Impedance Analysis (BIA) merek OMRON Body Composition Monitor HBF-375. Data konsumsi pangan meliputi asupan makan menggunakan formulir recall $2 \times 24 \mathrm{~h}$ dan kebiasaan makan menggunakan food frequency questionnaire (FFQ). Pengambilan sampel darah dilakukan oleh tenaga kesehatan menggunakan prosedur terstandar. Sebelum dilakukan pengambilan darah, subjek dipuasakan terlebih dahulu selama minimal 8 jam. Sampel darah diambil sekitar $5 \mathrm{cc}$ dari masing-masing subjek untuk 
selanjutnya digunakan dalam analisis kadar SOD (Randox Manual/RX Monza Labs. Cat. No. SD 125, Crumlin, UK) dan MDA (metode Will's). Setiap kelompok diinstruksikan untuk mengonsumsi minuman rosela ungu atau plasebo selama 6 minggu. Selama periode intervensi, kepatuhan subjek dikontrol menggunakan form monitoring dengan mengevaluasi volume minuman yang dihabiskan. Subjek tetap mengonsumsi makanan rumah sehari-hari dengan pembatasan pada makanan sumber antosianin ataupun suplemen dan obat-obatan yang dapat memengaruhi hasil intervensi. Pada akhir intervensi, dilakukan pengumpulan data kembali, meliputi antropometri, konsumsi makanan, dan parameter biokimia.

Data diolah dan dianalisis menggunakan program Microsoft Excel 2013, Nutrisurvey, dan SPSS 16.0. Data dianalisis secara deskriptif untuk mengetahui sebaran subjek berdasarkan tiap parameter. Uji beda paired t-test dilakukan untuk melihat perubahan sebelum dan setelah intervensi pada masing-masing kelompok. Uji beda Independent $t$-test untuk melihat perbedaan pada kedua grup. Analisis ANCOVA dilakukan untuk mengetahui variabel kovariat yang dapat terlibat mempengaruhi hasil penelitian. Hasil analisis dikatakan signifikan jika nilai $\mathrm{p}<0.05$.

\section{HASIL}

\section{Gambaran Umum Satuan Pengaman yang Mengalami Kegemukan}

Tabel 1 menunjukkan sebaran satpam yang mengalami kegemukan berdasarkan parameter yang ditentukan, meliputi umur, ukuran kuluarga, pendidikan, pendapatan, pengetahuan gizi, kebiasaan merokok, aktivitas fisik, IMT, persen lemak tubuh, dan lemak viseral. Skrining awal menunjukkan bahwa 77,8\% tersebar dalam kelompok umur dewasa madya dengan rata-rata $41,35 \pm 7,09$ tahun dan $75,3 \%$ berasal dari keluarga dengan anggota keluarga $\leq 4$ orang. Sebanyak 96,2\% satpam lulus SMA/sederajat. Sementara tingkat pendapatan berkisar Rp 1.500.000 ke atas.

Sebanyak $82,7 \%$ satpam memiliki kebiasaan merokok dan $85,4 \%$ memiliki tingkat aktivitas fisik ringan dengan rata-rata skor $1,57 \pm 0,23$. Nilai IMT satpam sebagian besar tersebar dalam kategori obesitas $(86,4 \%)$ dengan rata-rata $28,34 \pm 3,25 \mathrm{~kg} / \mathrm{m}^{2}$. Sementara, $79,0 \%$ subjek memiliki persen lemak tubuh sangat tinggi dengan rata-rata $26,90 \pm 3,42 \%$ dan $67,9 \%$ memiliki lemak viseral tinggi dengan rata-rata $14,66 \pm 4,28 \%$.

\section{Karakteristik Subjek}

Tabel 2 menunjukkan sebaran subjek yang mengikuti tahap intervensi berdasarkan data karakteristik sosial ekonomi dan status gizi. Data tersebut menunjukkan tidak ada perbedaan antara kedua kelompok sebelum intervensi ( $p>0.005)$. Demikian pula untuk nilai SOD dan MDA menunjukkan tidak ada perbedaan yang signifikan. Namun, jika dibandingkan dengan kadar SOD normal $(164-240 \mathrm{U} / \mathrm{mL})$, kadar SOD subjek pada kedua kelompok tergolong rendah dan berada di bawah kisaran normal dengan rata-rata SOD lebih tinggi pada kelompok intervensi. Sementara, kadar MDA subjek pada kedua kelompok tergolong tinggi dan berada di atas kadar normal $(<0,1308 \mu \mathrm{g} / \mathrm{mL})$ dengan rata-rata MDA lebih tinggi pada kelompok kontrol. Tingginya kadar MDA menandakan bahwa terjadi peningkatan stres oksidatif.

Tabel 1. Sebaran satuan pengaman dengan kegemukan

\begin{tabular}{|c|c|c|}
\hline Karakteristik & $\mathbf{n}$ & $\%$ \\
\hline \multicolumn{3}{|l|}{ Kelompok umur (tahun) } \\
\hline Dewasa awal $(<35)$ & 18 & 22,2 \\
\hline Dewasa madya $(36-55)$ & 63 & 77,8 \\
\hline \multicolumn{3}{|l|}{ Ukuran keluarga } \\
\hline Kecil $(\leq 4$ orang $)$ & 61 & 75,3 \\
\hline Sedang $(5-6$ orang $)$ & 17 & 21,0 \\
\hline Besar $(\geq 7$ orang $)$ & 3 & 3,7 \\
\hline \multicolumn{3}{|l|}{ Pendidikan } \\
\hline Lulus SMP/sederajat & 2 & 2,5 \\
\hline Lulus SMA/sederajat & 78 & 96,3 \\
\hline Lulus PT (D3-S3) & 1 & 1,2 \\
\hline \multicolumn{3}{|l|}{ Pendapatan } \\
\hline$<$ Rp 1.500.000,-/bulan & 8 & 9,9 \\
\hline Rp 1.500 000,- - Rp 2500 000,-/bulan & 37 & 45,7 \\
\hline Rp 2500 000,- - Rp 3500 000,-/bulan & 23 & 28,4 \\
\hline > Rp 3500 000,-/bulan & 13 & 16,0 \\
\hline \multicolumn{3}{|l|}{ Pengetahuan gizi } \\
\hline Baik $(>80 \%-100 \%)$ & 3 & 3,7 \\
\hline Sedang $(60 \%-80 \%)$ & 48 & 59,3 \\
\hline Kurang $(<60 \%)$ & 30 & 37,0 \\
\hline \multicolumn{3}{|l|}{ Kebiasaan merokok } \\
\hline Ya & 67 & 82,7 \\
\hline Tidak & 14 & 17,3 \\
\hline \multicolumn{3}{|l|}{ Jumlah rokok/hari } \\
\hline$\geq 21$ batang/hari & 30 & 44,8 \\
\hline $11-20$ batang/hari & 29 & 43,3 \\
\hline$\leq 10$ batang/hari & 8 & 11,9 \\
\hline \multicolumn{3}{|l|}{ PAL } \\
\hline Ringan $(1,40 \leq \mathrm{PAL} \leq 1,69$ & 70 & 85,4 \\
\hline Sedang $(1,70 \leq \mathrm{PAL} \leq 1,99)$ & 10 & 12,2 \\
\hline Berat $(2,00 \leq \mathrm{PAL} \leq 2,39)$ & 2 & 2,4 \\
\hline \multicolumn{3}{|l|}{ IMT } \\
\hline Overweight $\left(23,0-24,9 \mathrm{~kg} / \mathrm{m}^{2}\right)$ & 11 & 13,6 \\
\hline Obesitas $\left(>30,0 \mathrm{~kg} / \mathrm{m}^{2}\right)$ & 70 & 86,4 \\
\hline \multicolumn{3}{|l|}{ Lemak tubuh } \\
\hline Normal $(10 \%-<20 \%$ BB $)$ & 3 & 3,7 \\
\hline Tinggi $(20 \%-<25 \% \mathrm{BB})$ & 14 & 17,3 \\
\hline Sangat tinggi (>25 BB \%) & 64 & 79.0 \\
\hline \multicolumn{3}{|l|}{ Lemak viseral } \\
\hline Normal $(\leq 12)$ & 26 & 32,1 \\
\hline Tinggi $(>12)$ & 55 & 67,9 \\
\hline
\end{tabular}


Tabel 2. Sebaran subjek intervensi (data baseline)

\begin{tabular}{|c|c|c|c|}
\hline \multirow{2}{*}{ Fase } & \multicolumn{2}{|c|}{ Kelompok } & \multirow{2}{*}{ p-value } \\
\hline & Intervensi & Kontrol & \\
\hline Usia (tahun) & $42,67 \pm 6,91$ & $46,33 \pm 5,93$ & 0,245 \\
\hline \multicolumn{4}{|l|}{ Pendidikan } \\
\hline Lulus SMA/sederajat & $9(100,0)$ & $9(100,0)$ & \\
\hline \multicolumn{4}{|l|}{ Ukuran keluarga } \\
\hline Kecil ( $\leq 4$ orang) & $7(77,8)$ & $6(66,7)$ & 0,624 \\
\hline Sedang (5-6 orang) & $2(22,8)$ & $3(33,3)$ & \\
\hline \multicolumn{4}{|l|}{ Pendapatan (Rp) } \\
\hline$<1500000 /$ bulan & $1(11,1)$ & $0(0,0)$ & $\mathbf{0 , 3 3 6}$ \\
\hline 1500000 - 2500 000/bulan & $3(33,3)$ & $6(66,7)$ & \\
\hline 2500000 - 3500 000/bulan & $4(44,4)$ & $3(33,7)$ & \\
\hline > Rp 3500 000,-/bulan & $1(11,1)$ & $0(0,0)$ & \\
\hline \multicolumn{4}{|l|}{ Antropometri } \\
\hline $\mathrm{BB}(\mathrm{kg})$ & $77,37 \pm 10,0$ & $76,32 \pm 6,87$ & 0,799 \\
\hline $\operatorname{IMT}\left(\mathrm{kg} / \mathrm{m}^{2}\right)$ & $28,53 \pm 2,38$ & $27,46 \pm 2,36$ & 0,356 \\
\hline Lingkar pinggang $(\mathrm{cm})$ & $94,67 \pm 10,1$ & $92,83 \pm 6,07$ & 0,648 \\
\hline \multicolumn{4}{|l|}{ Gaya hidup } \\
\hline Aktivitas fisik & $1,55 \pm 0,07$ & $1,59 \pm 0,10$ & 0,348 \\
\hline \multicolumn{4}{|l|}{ Parameter biokimia } \\
\hline $\mathrm{SOD}(\mathrm{U} / \mathrm{mL})$ & $0,45 \pm 0,14$ & $0,42 \pm 0,12$ & 0,628 \\
\hline $\operatorname{MDA}(\mu \mathrm{g} / \mathrm{mL})$ & $0,30 \pm 0,06$ & $0,48 \pm 0,47$ & $\mathbf{0 , 2 7 1}$ \\
\hline
\end{tabular}

Keterangan: BB (Berat badan); IMT (indeks massa tubuh); SOD (superoksida dismutase); MDA (malondialdehid); signifikan $p<0.05$

Tabel 3. Efek minuman ekstrak rosela ungu terhadap antropometri

\begin{tabular}{lccc}
\hline Parameter & Fase & Intervensi & Kontrol \\
\hline BB $(\mathrm{kg})$ & Sebelum & $77,37 \pm 10,0$ & $76,32 \pm 6,87$ \\
& Setelah & $76,29 \pm 9,77$ & $76,18 \pm 7,01$ \\
& Selisih & $-1,08 \pm 1,06$ & $-0,14 \pm 1,73$ \\
& $p$-value & 0,015 & 0,808 \\
IMT $\left(\mathrm{kg} / \mathrm{m}^{2}\right)$ & Sebelum & $28,53 \pm 2,38$ & $27,46 \pm 2,36$ \\
& Setelah & $28,14 \pm 2,36$ & $27,40 \pm 2,32$ \\
& Selisih & $-0,39 \pm 0,37$ & $-0,06 \pm 0,62$ \\
Lingkar pinggang $(\mathrm{cm})$ & -value & 0,013 & 0,769 \\
& Sebelum & $94,66 \pm 10,14$ & $92,83 \pm 6,06$ \\
& Setelah & $91,77 \pm 8,72$ & $91,05 \pm 6,12$ \\
& Selisih & $2,88 \pm 2,73$ & $1,77 \pm 1,78$ \\
Lemak viseral $(\%)$ & $p$-value & 0,013 & 0,017 \\
& Sebelum & $15,25 \pm 3,40$ & $14,13 \pm 3,06$ \\
& Setelah & $14,66 \pm 3,36$ & $14,06 \pm 2,96$ \\
Lemak tubuh $(\%)$ & Selisih & $-0,58 \pm 0,72$ & $-0,07 \pm 0,82$ \\
& $p$-value & 0,043 & 0,800 \\
& Sebelum & $26,51 \pm 3,93$ & $26,53 \pm 2,23$ \\
& Setelah & $25,65 \pm 4,70$ & $26,44 \pm 3,00$ \\
& Selisih & $-0,86 \pm 2,10$ & $-0,08 \pm 2,00$ \\
\hline
\end{tabular}

Keterangan: BB (Berat badan); IMT (indeks massa tubuh); signifikan $p<0,05$

Efek Minuman Ekstrak Rosela Ungu terhadap Antropometri

Tabel 3 menunjukkan efek intervensi terhadap parameter antropometri subjek setelah 6 minggu masa intervensi. Hasilnya menunjukkan bahwa ekstrak kelopak rosela ungu signifikan menurunkan berat badan, IMT, lingkar pinggang, dan lemak viseral pada kelompok intervensi, namun secara statistik efek tersebut tidak berbeda jika dibandingkan dengan kelompok kontrol. Lemak tubuh pada kelompok intervensi tidak berbeda signifikan, walaupun mengalami penurunan.

Tabel 4 menyajikan efek intervensi ekstrak rosela ungu terhadap kadar SOD dan MDA. Pemberian ekstrak rosela ungu signifikan meningkatkan kadar SOD pada kelompok intervensi, namun secara statistik tidak berbeda signifikan dengan kelompol kontrol. Pemberian ekstrak rosela ungu tidak dapat menurunkan kadar MDA pada kelompok intervensi. 
Tabel 4. Efek minuman ekstrak rosela ungu terhadap kadar SOD dan MDA

\begin{tabular}{ccccc}
\hline Parameter & Fase & Rosela & Kontrol & p-value \\
\hline SOD $(\mathrm{U} / \mathrm{mL})$ & Sebelum & $0,45 \pm 0,14$ & $0,42 \pm 0,12$ & \\
& Setelah & $1,35 \pm 0,71$ & $1,90 \pm 0,85$ & 0,128 \\
& selisih $(\Delta)$ & $0,89 \pm 0,77$ & $1,49 \pm 0,80$ & $0,001^{*}$ \\
MDA $(\mu \mathrm{g} / \mathrm{mL})$ & p-value & $0,008^{*}$ & $0,484 \pm 0,471$ & 0,473 \\
& Sebelum & $0,303 \pm 0,062$ & $0,359 \pm 0,331$ & $-0,125 \pm 0,60$ \\
& Setelah & $0,319 \pm 0,730$ & 0,554 & \\
& selisih $(\Delta)$ & $0,025 \pm 0,083$ & 0,629 &
\end{tabular}

Tabel 5. Hasil analisis kovariat (ANCOVA) berat badan dan SOD

\begin{tabular}{cc}
\hline \multicolumn{1}{c}{ Variabel kovariat } & p-value \\
\hline Variabel dependen: berat badan akhir & \\
Berat badan & $0,000^{*}$ \\
Indeks massa tubuh & 0,215 \\
Lemak tubuh & 0,172 \\
Lemak viseral & 0,196 \\
Perlakuan & 0,328 \\
Variabel dependen : kadar SOD akhir & \\
Lemak tubuh & $0,018^{*}$ \\
Indeks massa tubuh & $0,004^{*}$ \\
Asupan Cu & 0,107 \\
Asupan Zn & 0,061 \\
Asupan Vitamin C & $0,029 *$ \\
Asupan Vitamin E & 0,101 \\
Perlakuan & 0,470 \\
\hline signifikan $p<0.05$ &
\end{tabular}

Tabel 5 menyajikan hasil analisis ANCOVA untuk variabel dependen berat badan dan SOD. Uji ANCOVA dilakukan untuk melihat variabel kovariat yang mungkin ikut serta memengaruhi perubahan yang terjadi pada variabel uji selain dari perlakuan yang diberikan. Hasil analisis ANCOVA menunjukkan bahwa variabel kovariat yang dapat memengaruhi perubahan berat badan adalah berat badan awal $(p<0,05)$, sementara perubahan kadar SOD dapat dipengaruhi oleh indeks massa tubuh awal $(p<0,05)$.

\section{PEMBAHASAN}

Skrining awal menunjukkan bahwa 77,8\% satpam yang mengalami kegemukan berusia di atas 36 tahun dengan 86,4\% mengalami obesitas dan 13,6\% overweight. Suatu penelitian mengatakan bahwa obesitas meningkat seiring bertambahnya usia baik pada laki-laki maupun perempuan ${ }^{25}$. Rentang usia tersebut merupakan masa produktif sehingga kejadian kegemukan yang terjadi dapat disebabkan oleh gaya hidup, khususnya aktivitas fisik yang rendah dan pola konsumsi terkait pangan tertentu, seperti makanan tinggi lemak. Sebanyak 79,0\% memiliki lemak tubuh sangat tinggi. Berdasarkan hasil analisis didapatkan korelasi yang signifikan antara indeks massa tubuh dengan persen lemak tubuh dan lemak viseral. Penelitian menyatakan bahwa indeks massa tubuh berkorelasi dengan persen lemak tubuh ${ }^{26}$ dan merupakan faktor risiko penyakit tidak menular. Demikian pula dengan lemak viseral, sebanyak $67,9 \%$ memiliki lemak viseral tinggi yang dapat dikaitkan dengan risiko obesitas sentral.

Sebanyak 82,7\% memiliki kebiasaan merokok dengan rata-rata jumlah rokok per hari sebanyak 11 batang atau lebih. Subjek merupakan perokok tetap atau rutin dengan rata-rata usia pertama merokok sekitar 18 tahun. Hal tersebut menunjukkan bahwa subjek telah lama memiliki kebiasaan merokok. Penelitian tahun 2015 menemukan bahwa terdapat hubungan positif antara merokok dengan linkar pinggang dan rasio pinggang pinggul dengan menghubungkan jumlah rokok serta durasi waktu merokok. Hal ini menunjukkan bahwa, kebiasaan merokok dapat memengaruhi pola distribusi lemak khususnya lemak pada bagian adiposit sentral. Mekanisme biologi yang mungkin terjadi yaitu adanya efek antiestrogenik yang meningkatkan 2hidroksilasi estradiol atau menginduksi ketidakseimbangan dalam androgenik terhadap aktivitas estrogenik. Merokok juga dapat meningkatkan pengaturan dan penyimpanan asam lemak trigliserida oleh adiposit sehingga meningkatkan massa lemak ${ }^{4}$.

Nilai rerata physical activity level (PAL) sebesar 1,576 dan tergolong ringan. Aktivitas fisik sedentary berkaitan dengan peningkatan IMT dan lemak tubuh ${ }^{6,27}$ disebabkan oleh pengurangan pengeluaran energi untuk aktivitas fisik. Berdasarkan recall 24 hours aktivitas fisik menunjukkan bahwa aktivitas subjek lebih banyak melakukan pekerjaan dengan intensitas ringan. Sementara, salah satu prinsip dalam penurunan berat badan adalah dengan melakukan aktivitas fisik. Aktivitas fisik selama 150 menit setiap minggu dengan intensitas sedang hingga tinggi, misalnya jalan cepat dapat mengurangi berat badan sebesar $1 \%$ hingga $3 \% .^{28}$ Sementara, berdasarkan hasil recall 24 hours menunjukkan tingkat kecukupan energi, protein, lemak, dan karbohidrat berada pada kategori defisit dengan ratarata asupan berturut-turut yaitu $1610,1 \pm 440,4$ kal; $53.8 \pm 15,7 \mathrm{~g} ; 60,4 \pm 24,4 \mathrm{~g} ; 235,5 \pm 68,6 \mathrm{~g}$.

Sebanyak delapan belas subjek mengikuti penelitian tahap intervensi hingga akhir. Karakteristik subjek dapat dilihat pada Tabel 2. Analisis statistik menunjukkan karakteristik subjek pada kedua kelompok 
tidak memiliki perbedaan signifikan $(p>0,05)$. Kondisi homogen sebelum intervensi diharapkan untuk mengurangi kemungkinan bias pada hasil penelitian. Pemberian intervensi minuman rosela ungu signifikan menurunkan berat badan $(1,08 \mathrm{~kg})$ dan IMT $\left(0,39 \mathrm{~kg} / \mathrm{m}^{2}\right)$ pada kelompok intervensi. Begitu pula dengan kelompok kontrol, mengalami penurunan berat badan $(0,14 \mathrm{~kg})$ dan IMT $\left(0,06 \mathrm{~kg} / \mathrm{m}^{2}\right)$ namun penurunan tersebut tidak berbeda signifikan. Penurunan nilai antropometri pada kelompok intervensi menunjukkan adanya efek positif dari kandungan polifenol rosela ungu, salah satunya antosianin dalam penurunan berat badan. Hal tersebut telah dibuktikan pada penelitian sebelumnya yang menyatakan bahwa pemberian bahan pangan kaya antosianin dapat menurunkan berat badan ${ }^{30}$. Penurunan nilai antropometri pada kelompok kontrol diduga disebabkan oleh penurunan asupan makan selama proses intervensi. Data recall $2 \times 24$ hours setelah intervensi menunjukkan asupan energi, protein, lemak, dan karbohidrat subjek pada kelompok kontrol mengalami penurunan dibanding sebelum intervensi dan penurunan tersebut lebih besar dibandingkan dengan yang terjadi pada kelompok intervensi (Energi 1510,4 $\pm 363,8 \mathrm{kkal}$ menjadi $1432,7 \pm 297,3 \mathrm{kkal}$; protein $50,8 \pm 16,2 \mathrm{~g}$ menjadi $49,4 \pm 22,3$; lemak $55,2 \pm 19,6$ g menjadi $53,6 \pm 20,4$ g; KH $221,0 \pm 49,4$ g menjadi $211,4 \pm 39,8 \mathrm{~g}$ ).

Rosela ungu merupakan pangan kaya antosianin, sehingga berpotensi digunakan dalam pencegahan maupun pengobatan kegemukan. Pengobatan dianggap berhasil jika mampu mencegah penambahan berat badan lebih lanjut dan menginduksi penurunan berat badan 5 $10 \%$ dari berat badan awal. Suatu penelitian menyatakan bahwa pemberian ekstrak rosela yang mengandung $33,64 \mathrm{mg}$ total antosianin mengurangi kenaikan berat badan $9,6 \%$ pada tikus ${ }^{31}$. Efek antiobesitas dari antosianin dapat melalui perubahan jalur pensinyalan mitogen activated protein kinase (MAPK) dan nuclear factor-kB (NF-kB) yang menunjukkan peran sitoprotektif dan antiinflamasi dalam patologi obesitas ${ }^{32}$. Selain itu juga melalui pengurangan lemak intraperitoneal dan peningkatan aktivitas peroxisome proliferator-activated receptor (PPAR) pada jaringan adiposa putih dan otot skeletal tikus. ${ }^{16}$

Hasil penelitian menunjukkan bahwa minuman rosela ungu dapat meningkatkan $0,89 \mathrm{U} / \mathrm{mL}$ kadar SOD subjek pada kelompok intervensi. Kelopak rosela memiliki aktivitas antioksidan tertinggi dibandingkan bagian lainnya seperti daun dan batang rosela ${ }^{33}$ dengan jenis antioksidan yang kuat. Hasil ini serupa dengan penelitian sebelumnya bahwa kelopak rosela kaya akan vitamin C (141 mg/100 g), antosianin (252 mg/100 g), $\beta$ karoten $(1.88 \mathrm{mg} / 100 \mathrm{~g})$, dan likopen $(164 \mu \mathrm{g} / 100 \mathrm{~g})^{34}$. Namun, aktivitas antioksidan ini akan mengalami penurunan jika mengalami penyimpanan pada suhu rendah $\left(0\right.$ sampai $\left.5{ }^{\circ} \mathrm{C}\right)$ setelah 30 hari ${ }^{35}$. Jika dibandingkan rata-rata peningkatan kadar SOD pada kedua kelompok, kelompok kontrol mengalami peningkatan yang lebih tinggi. Analisis ANCOVA menunjukkan bahwa IMT, lemak tubuh, dan asupan vitamin $\mathrm{C}$ signifikan memengaruhi kadar SOD. Amirkhizi tahun 2014 menyatakan bahwa kadar SOD pada kondisi kegemukan lebih rendah dibandingkan pada berat badan normal. Produksi radikal bebas yang tinggi pada kegemukan akan menekan antioksidan enzim, salah satunya SOD. Data awal sebelum intervensi menunjukkan rerata IMT pada kelompok rosela lebih tinggi dibandingkan dengan kontrol, walaupun secara statistik tidak berbeda secara signifikan. Selain itu, asupan vitamin pada kelompok kontrol lebih tinggi dibandingkan kelompok rosela walaupun tidak berbeda signifikan secara statistik. Hal ini diduga yang mempengaruhi kadar SOD pada kelompok kontrol.

Selain faktor yang telah disebutkan sebelumnya, peningaktan kadat SOD yang lebih tinggi pada kelompok kontrol diduga dipengaruhi oleh asupan asupan mineral mikro pada subjek, khususnya mineral $\mathrm{Cu}$ dan $\mathrm{Zn}$. Asupan $\mathrm{Cu}$ dan $\mathrm{Zn}$ pada kelompok kontrol ditemukan lebih tinggi dibandingkan dengan kelompok intervensi sebelum intervensi. Sementara itu, SOD merupakan antioksidan metaloenzim, yaitu antioksidan yang mekanisme kerja dan aktivitasnya melibatkan serta dipengaruhi oleh logam katalitik, diantaranya $\mathrm{Cu}$ dan $\mathrm{Zn}$. $\mathrm{Zn}$ berperan terhadap peningkatan aktivitas SOD melalui pelipatan protein dan kestabilan SOD. Selain itu, dengan cara menstimulasi limfosit $\mathrm{T}$ untuk berproliferasi sehingga memacu aktivitas enzim selular. ${ }^{36}$ Sementara, ion $\mathrm{Cu}$ berperan dalam aktivitas SOD dalam mengais ion superoksida melalui reaksi reduksi dan reoksidasi pada lokasi $\mathrm{SOD}^{37}$. Hal ini menjelaskan bahwa, kondisi terbatasnya senyawa logam, utamanya $\mathrm{Cu}$ dan $\mathrm{Zn}$ dapat memengaruhi aktivitas dan kestabilan SOD khususnya dalam menangkal radikal bebas.

Penelitian ini juga menemukan bahwa pemberian intervensi minuman rosela ungu tidak memberikan perbedaan sginifikan pada kadar MDA. Hasil ini sejalan dengan penelitian yang dilakukan kepada pasien sindrom metabolik dengan pemberian kapsul berisi $500 \mathrm{mg}$ tepung rosela (antosianin sebesar 6 $\mathrm{mg} / \mathrm{g}$ tepung) selama 4 minggu tidak menunjukkan perbaikan pada kadar MDA. Demikian pula dengan penelitian pada tikus yang diberikan makanan diperkaya antosianin (total antosianin $110 \mathrm{mg} / \mathrm{kg} \mathrm{dwb}$ ) selama 2 bulan menunjukkan peningkatan pada peroksida lipid. Meskipun dalam penelitian ini tidak ditemukan adanya perbaikan kadar MDA dengan pemberian rosela ungu, namun beberapa penelitian telah menunjukkan adanya perbaikan tingkat stres oksidatif setelah pemberian rosela yaitu penurunan kadar MDA. Penelitian Ilyas et al. (2017) pada tikus yang mendapat overtraining, diberi perlakuan rosela $400 \mathrm{mg} / \mathrm{kg} / \mathrm{hari}$ selama 11 minggu dapat menurunkan MDA serta meningkatkan antioksidan GPx. Demikian pula penelitian yang dilakukan oleh Hadi et al. 
(2016) pada atlit sepak bola dengan memberikan kapsul yang mengandung antosianin 25,463 mg selama 6 minggu menunjukkan penurunan MDA secara signifikan.

Aktivitas antioksidan dari antosianin menunjukkan efek penghambatan pada pembentukan MDA. Penghambatan pembentukan MDA tergantung pada konsentrasi setiap antosianin yang ditambahkan. Beberapa antosianin dapat menghambat NADPH mikrosomal dan menghasilkan hibridasi pembentukan MDA, namun beberapa diantaranya juga memungkinkan untuk tidak dapat menghambat. Hal tersebut tergantung pada struktur antosianinnya yang dipengaruhi oleh jumlah gugus hidroksil pada cincin B dan gugus karbonilnya. Jumlah gugus hidroksil pada cincin-B yang meningkat akan meningkatkan aktivitas pemulungan radikal bebas pada tingkat glikosida, sementara keberadaan gugus glukosa pada posisi C-3 melemahkan aktivitas pemulungan $\mathrm{OH}^{-}$antosianin. Selain itu, flavylium antosianin stabil dalam kondisi asam dan akan mengalami perubahan struktur pada kondisi netral dan basa, bahkan mengalami kerusakan sehingga tidak mampu melakukan aktivitas pemulungan ROS atau radikal hidroperoksida lipid.

\section{SIMPULAN}

Pemberian minuman rosela ungu dengan kandungan antosianin 81,16 mg selama 6 minggu dapat meningkatkan SOD sebesar 0,89 U/mL. Hasil ini dapat dianggap sebagai potensi pemanfaatan rosela ungu dalam meningkatkan kadar antioksidan pada kegemukan. Sementara, kadar MDA tidak berbeda signifikan pada kedua kelompok. Oleh karena itu diperlukan penelitian lanjutan dengan ukuran sampel yang lebih besar, serta periode waktu intervensi yang lebih lama dengan berbagai takaran dosis pemberian untuk mendeteksi manfaat kandungan antosianin rosela ungu bagi kegemukan.

\section{UCAPAN TERIMA KASIH}

Ucapan terima kasih kepada Politeknik Kesehatan Kementerian Kesehatan Sorong dan Badan Pengembangan dan Pemberdayaan Sumber Daya Manusia Kesehatan Kementerian Kesehatan RI yang telah memberikan dukungan atas terlaksananya penelitian.

\section{DAFTAR PUSTAKA}

1. WHO. Obesity and Overweight [internet]. Media Center World Health Organization. 2017 (diakses pada 1 Agustus 2017) di alamat http://www.who.int/gho/ncd/risk_factors/overweig ht/en/

2. Park KY, Park HK, Hwang HS. Relationship between abdominal obesity and alcohol drinking pattern in normal-weight, middle-aged adults: the korea national health and nutritional examination survey 2008-2013. Publ H Nutr. 2017. 20(12): 2192-2200. doi: 10.1017/S1368980017001045

3. Selvant, Ramadurg, Dorle, Ghattargi, Banada. A Cross-Sectional Study on Pattern of Alcohol Consumption and Body Mass Index Among Health Institution Students in Bagalkot. J Clin Diagn Res. 2015. 9(12): 6-9

4. Canoy D, Wareham N, Luben R, Welch A, Bingham S, Day N, Khaw KT. Cigarette Smoking and Fat Distribution in 21. 828 British Men and Women: A Populationbased Study. Obes Res. 2005. 13(2005)

5. Drapeau V, Despres JP, Bouchard C, Allard L, Fournier G, Leblanc C, Tremblay A. Modification in food-group consumption are related to long-term body-weight changes. AJCN. 2004. 80(2004):2937. doi: 10.1093/ajen/80.1.29.

6. Jakicic JM, Greg E, Knowler W, Kelley DE, Lang W, Miller GD, Pi-Sunyier FX, Regensteiner JG, Rejeski WJ, Ribisl P, et al. Activitiy patterns of obese adults with type 2 diabetes in the Look AHEAD study. Med Sci Sports Exerc. 2010. 42(11):1995-2005.

doi: 10.1249/MSS.0b013e3181e054f0.

7. Vincent HK, Innes KE, Vincent KR. Oxidative stress and potential interventions to reduce oxidative stress in overweight and obesity. Diabetes, Obes, Met. 2007. 9(2007):813-839. doi: 10.1111/j.1463-1326.2007.00692.x

8. Amirkhizi F, Siassi F, Djalali M, Shahraki SH. Impaired enzymatic antioxidant defense in erythrocytes of women with general and abdominal obesity. Obes Res Clin Prac. 2014. 8(2014):e26e34. doi: 10.1016/j.orcp.2012.07.004

9. Basu A, Betts NM, Ortiz J, Simmons B, Wu M, Lyons TJ. Low-energy cranberry juice decrease lipid oxidation and increases plasma antioxidant cpacity in women with metabolic syndrome. Nutr Res. 2011. 31(2011):190-196. doi: 10.1016/j.nutres.2011.02.003

10. Jansakova K, Babickova J, Havrientova M, Hodosy J, Kraic J, Celec P, Tothova L. The effects of anthocyanin rich wheat diet on the oxidative status and behavior of rats. Croat Med J. 2016. (57):119129. doi: 10.1016/j.jep.2003.09.008

11. Qin Y, Xia M, Ma J, Ho Y, Liu J, Mou H, Cao L, Ling W. Anthocyanin supplementation improves serum LDL- and HDL-cholesterol concentrations associated with the inhibition of cholesteryl ester transfer protein in dyslipidemic subjects. Am J Clin $\begin{array}{lll}\text { Nutr. } & 2009 . & \text { (90):485-492. doi: }\end{array}$ 
10.3945/ajen.2009.27814

12. Suarez JMA, Giampieri F, Tulipani S, Casoli T, Stefano GD, Ana M, Paramas G, Buelga CS, Busco F, Quiles JL, et al. One-month strawberry-rich anthocyanin supplementation ameliorates cardiovascular risk, oxidative stress markers and platelet activation in humans. J Nutr Biochem. 2014. (25):289-294. doi:10.1016/j.jnutbio.2013.11.002

13. Basu A, Du M, Leyva MJ, Sanchez K, Betts NM, Wu M, Aston CE, Lyons TJ. Blueberries decrease cardiovasculer risk factors in obese men and women with metabolic syndrom. J Nutr. 2010. 140(2010):1582-1587. doi: 10.3945/jn.110.124701

14. Zhu Y, Ling W, Guo H, Song F, Ye Q, Zou T, Li D, Zhang Y, Li G, Xiao Y et al. Anti-inflammatory effect of purified dietary anthocyanin in adults with hypercholesterolemia: A randomized controlled trial. Nutr, Metabolisme and Cardiovascular Disease. 2013. 23:843-849. doi: 10.1016/j.numecd.2012.06.005

15. Vendrame S, Daugherty A, Kristo AS, Riso P, Zacas DK. Wild blueberry (Vaccinium angustifolium) consumption improves inflammatory status in the obese Zucker rat model of the metabolic syndrome. J Nutr Biochem. 2013. (24):1508-1512. doi:10.1016/j.jnutbio.2012.12.010

16. Seymour EM, Tanone II, Daniel E, Llanes U, Lewis Sk, Kirakosyan A, Kondoleon MG, Peter B, Kaufman, Bolling SF. J Med Food. 2011. 14(12):1511-1518. doi:10.1089/jmf.2010.0292

17. Wu T, Tang Q, Gao Z, Yu Z, Song H, Zheng X, Chen W. Blueberry and Mulberry Juice Prevent Obesity Development in C57BL/6 Mice. Plos One. 2013. 8(10):e77585

18. Suzery M, Lestari S, Cahyono B. Penentuan total antosianin dari kelopak bunga rosela (Hibiscus sabdariffa L) dengan metode maserasi dan sokshletasi. J Sains Math. 2010. 18(1):1-6.

19. Djaeni M, Ariani N, Hidayat R, Utari FD. Ekstrak antosianin dari kelopak bunga rosela (Hibiscus sabdariffa L.) berbantu ultrasonik:tinjauan aktivitas antioksidan. J Apl Tekn Pang. 2017. 6(3):148-151. doi: 10.17728/jatp.236

20. Ezzat SM, Salama MM, el-Din SHS, Saleh S, Lakkany NME, Hammam OA, Salem MB, Botros SS. Metabolyc profile and hepatoprotective activityof the anthocyanin-rich etract of Hibiscus sabdariffa calyces. Pharm Biol. 2016. 1(2016):1-10. doi: 10.1080/13880209.2016.1214739.

21. Ilyas EII, kartinah NT, Andriani T, Goernarjo RA, Kahanjak DN, Freisleben HJ. Effects of Hibiscus sabdariffa Linn. on malondialdehyde and glutathione peroxide in an overtraining rat model characterized by growth hormone, insulin-like growth factor-1, and insulin-like growth factor binding potein-3. Biomed Pharm J. 2017. 10(1):1927. doi:10.13005/bpj/1076.

22. Hadi A, Pourmasoumi M, kafeshani M, Karimiah J, Maracy MR, Entezari MH. The effect of green tea and sour tea (Hibiscus sabdariffa L.) supplementation on oxidative stress and muscle damage in athletes. J Diet Supp. 2016. 0(0):1-12. doi: 10.1080/19390211.2016.1237400.

23. Christian KR, Jackson JC. Changes in total phenolic and monomeric anthocyanin composition and antioxidant activity of three varieties of sorrel (Hibiscus sabdariffa) during maturity. J Food Composit and Anal. 2009. 22:663-667. doi:10.1016/j.jfca.2009.05.007

24. Asgary S, Soltani R, Zolghadr M, Keshvari M, Sarrafzadegan N. Evaluation of the effects of roselle (Hibiscus sabdariffa L.) on oxidative stress and serum levels of lipids, insulin, and hs-CRP in adults patients with metabolic syndrome: a double blind placebo-controlled clinical trial. J Complement Integr Med. 2016. (2016):1-6. doi: 10.1515/jcim2015-0030.

25. Serra LM, Bautista IC. Etiology of obesity: two "key issues" and other emerging factors. Nutr Hosp. . 2013. 28(5):32-43.

26. Zhao D, Li Y, Zheng L, Yu K. Brief Communication: Body Mass Index, Body Adiposity Index, and Percent Body Fat in Asians. American J Phys Anthro. 2013. (00):0000.doi:10.1002/ajpa.22341

27. Thibault H, Contrand B, Saubusse E, Baine M, Tison SM. Risk factor for overweight and obesity in French adolescent: Physical activity, sedentary behavior and parental characteristics. Nut. 2010. 26(2010):192-200. doi: 10.1016/j.nut.2009.03.015

28. Jakicic JM, Kelliann K, Davis. Obesity and physical activity. Psychiatr Clin N Am. 2011. 34(2011):829840. doi: 10.1016/j.psc.2011.08.009

29. Dam RM, Seidell J. Carbohydrate intake and obesity. European J Clin Nutr. 2007. 61(1):575-599.

30. Azzini E, Giacometti J, Russo GL. 2017. Antiobesity effects of anthocyanins in preclinical and clinical studies. Hindawi. 2017:1-12.doi: $10.1155 / 2017 / 2740364$

31. Aguilar F, Zamilpa A, Garcia D, Almanza J, Romero E, Campos E, Carillo L, Ramos R. 2007. Effect of Hibiscus sabdariffa on obeity in MSG mice. $J$ Ethnopharmacology. 114:66-71.doi: 10.1016/j.jep.2007.07.020

32. DeFuria J, Bennett G, Strissel et al. Dietary blueberry attenuates whole-body insulin resistance in high fat-fed mice by reducing adipocyte death and its inflammatory sequelae. J Nutr. 2009. 139:1510-1516

33. Furukawa S, Fujita T, Shimabukuro M, Iwaki M, Yamada Y, Nakajima Y, Nakayama O, Makishima 
M, Matsuda M, Shimomura I. Increased oxidative stress in obesity and its impact on metabolic syndrome. J Clin Inves. 2004. (114):1752-1761. doi:10.1172/JCI200421625

34. Esa NM, Hern FS, Ismail A, Yee CL. Antioxidant activity in different parts of roselle (Hibiscus sabdariffa L.) extracts and potential exploitation of the seeds. Food Chem. 2010. (122):1055-1060. doi:10.1016/j.foodchem.2010.03.074

35. Wong PK, Yusof S, Ghazali HM, Man YBC. Physico-chemical characteristics of roselle (Hibiscus sabdarriffa L.). Nutr Food Scien. 2002.
32(2): 68-73. doi:10.1108/00346650210416994

36. Juniarka IGA, Lukitaningsih E, Noegrohati S. Analisis aktivitas antioksidan dan kandungan antosianin total ekstrak dan liposom kelopak bunga rosela (Hibiscus Sabdariffa L.). Majalah Obat Tradisi. 2011. 16(3):115-123

37. Tanaka Y, Shiozawa S, Morimoto I, Fujita T. Zinc inhibit pokeweed mitogen-induced development of immunoglobulin-secreting cells through augmentation of CD4 and CD8 cells. Int J Immunopharmachol. 1989. 11(6):673-679777 